\title{
Practice-Oriented Approach to Training Tutors at the Siberian Federal University
}

\author{
Vera V. Korshunova* \\ Siberian Federal University \\ 79 Svobodny, Krasnoyarsk, 660041, Russia
}

Received 26.12.2018, received in revised form 24.01.2019, accepted 06.02.2019

The article demonstrates the possibilities of a practice-oriented approach to training tutors for the regional education system: such specialists are needed in the new social conditions of Siberia. The research is based on the empirical analysis of the educational services market for training tutors in Russia and the demands by regional employers for tutors. Indicators of successful training of tutors are their educational results achieved in accordance with the requirements of the Federal State Educational Standard of Higher Education and the professional standard of the tutor. Practice-oriented training of bachelors, coupled with varying the content of educational programs and increasing the share of practice and practical exercises, contributes to building up strategies for professional growth of future tutors, strengthening their adequate professional self-esteem and developing the personal traits required for a qualified specialist. The authors propose a new model of practiceoriented training of tutors, including their participation in educational events and professional tests during the university study period. The article describes the experience of Institute of Education, Psychology and Sociology at the Siberian Federal University in enhancing the practical component of vocational training, choosing teaching methods, their methodological support and innovative character of organizing student practices within the "Pedagogical Education (Tutor)" area of study.

Keywords: student teaching practice, tutor, open educational space, tutorial model, contents of teaching programs, professional skills of students.

Research area: pedagogy.

Citation: Korshunova, V.V. (2019). Practice-oriented approach to training tutors at the Siberian Federal University. J. Sib. Fed. Univ. Humanit. soc. sci., 12(2), 164-174. DOI: 10.17516/19971370-0386.

(c) Siberian Federal University. All rights reserved

* Corresponding author E-mail address: wera7@mail.ru

This work is licensed under a Creative Commons Attribution-NonCommercial 4.0 International License (CC BY-NC 4.0). 


\section{Introduction}

Tutoring as a pedagogical practice dates back to the experience of foreign countries. The phenomenon of tutoring is closely related to the history of European universities. Historically, "tutor" as a word originated in Oxford and Cambridge within the system of private universities in England. The main educators were professors who gave lectures and assistants who participated in the practical classes. Also, the educational process included specialists who lined up an individual educational program together with the student. And these were called tutors (Smolianinova et al., 2015).

In the leading educational systems of the world (Great Britain, USA, Finland, Japan and France) there is a system of tutoring based on the idea of individualization, at the same time offering some specific component taking into account the national context.

\section{Theoretical framework}

The traditional foreign structure of tutoring has three realizations: supervision for the implementation of the educational process; moral coaching, which implies socialization and integration in the university environment; tutoring, building student learning strategies during the school year (Bespalova, 2007).

The Russian scientific and professional community has been studying tutoring for almost 25 years. The active study of tutoring as a practice began in Tomsk in 1990 . During this period, groups of educational institutions plunged into the development of tutoring, rethinking the existing Russian and foreign experience. Tomsk regional site hosted the following educational institutions: the school "Eureka-Development" (chaired by T.M. Kovaleva), the school of joint activities (G.N. Prozumentova), the School of Humanitarian Education (A.A. Popov, I.D. Proskurovskaia), who proffered their own approaches to understanding the concept of tutoring. The diversity of these techniques allowed specialists to get a productive general understanding of tutoring, considering the specifics of Russian education (Kovaleva, 2013).

The development of modern pedagogical practices of tutor support in the Russian education system is largely connected with the change in the social and cultural educational paradigm, which is now oriented towards meeting the needs of consumers of educational services.

In this regard, it is necessary to ensure the variability and individualization of education, which determines the processes of implementation of support technologies in education. The provision for the learning process on the basis of individual educational programs contributes to the creation of open educational systems and actualizes 
modernization of education, aimed at the most complete satisfaction of social needs for getting new professionals.

The professional tutors are wanted in different educational institutions of various levels: in kindergartens, schools, institutions of secondary vocational and higher education, organizations of inclusive and distance education, family centres.

According to the Yandex.Rabota web-site, the total number of vacancies for tutors throughout Russia was 83 as for December 20, 2018. The salary level was specified for 65 vacancies. The average salary of a tutor in the country is 37,000 rubles, in Moscow it reaches 60,000 rubles. The most promising conditions are advertised by private kindergartens, schools, educational centres.

The prospective candidates for the position of a tutor are searched for in Moscow, St. Petersburg, Tomsk, Yekaterinburg, Krasnoyarsk, Chelyabinsk, Novosibirsk and other cities.

Ensuring the availability of high quality education for tutors in accordance with their educational needs requires creating an individual educational path together with the tutors themselves, which would enable them to plan for the future.

In any educational institution there is a need to create conditions for the individual educational activity of each student in the process of the developing their abilities for self-determination, self-organization, and understanding of educational and professional horizons.

A tutor as a specialist is different from a teacher, a school counsellor or a psychologist. The main task of the school teacher is training, while the psychologist who works in the field of education is responsible for counselling and psychological assistance. A tutor is a special type of a teacher. The tutor's mission is the individual support of the student in the educational movement, help to reveal and realize students' personal potential.

The methodology of training such specialists in Russia has not been sufficiently developed yet. Meanwhile, it is obvious that the professional training of tutors, paying special attention to the specifics of professional activity, implies getting an academic education.

The tendency of education personalization promotes popularity of the tutor profession and makes pedagogical universities prepare unique specialists who will be able to accompany the students on their individual educational path.

Some pedagogical universities of Russia begin teaching this profession only at the Master level. 
Moreover, as President of the Interregional Tutor Association Tatiana Kovaleva noted, the majority of students entering the postgraduate courses (for a Master's degree) do not have any experience in tutoring (Kasprzhak, Kalashnikov, 2014).

In this connection, the goal of existing Master programs is the development of teachers focused on the implementation of support methods and individual educational paths.

It is worth mentioning that at the moment several Russian universities offer specialized programs for training tutors at the Master's level.

For example, since 2000 the Department of Individualization and Tutoring at theMoscow State Pedagogical University has been teaching students within the Master's program "Tutoring in Education" and on professional retraining courses "Tutoring support for educational activities".

In 2017, a Master's program was launched at the Moscow City Pedagogical University, as well as there was organized a joint internship in distance tutoring support by the Interregional Tutor Association and the Association for Developmental Education (MARO).

During the discussion on the preparation of a tutor within the professional community it has been suggested that in the future it is planned to open new Master's programs to train narrow specialists who will work purposefully with gifted children, children with limited health capabilities, and senior people.

Currently, the programs of the first stage of higher education which teach the profession of a tutor are undergraduate programs within the enlarged group of specialities "Education and Pedagogical Sciences". The programs include the Bachelor's program "Psychology of Education" at the Moscow State Pedagogical University, Peoples' Friendship University of Russia, the Russian State Pedagogical University named after Herzen, Kuban State University, Samara State University of Social Sciences and Education, North-Caucasus Federal University, Novosibirsk State Pedagogical university, Saratov State University named after N.G. Chernyshevsky. The purpose of these basic educational programs is to prepare bachelors within the field of "Pedagogical Education" (Margolis, 2014).

\section{Statement of the problem}

In 2014, understanding the importance of training such high level specialists the Institute of Education, Psychology and Sociology of Siberian Federal University designed a unique basic educational program within the field "Pedagogical Education" (profile - "Tutor"). 
According to the plan, the program "Tutor" is a consolidation of the analyses of scientific and practical results, based on the unity of the theory of tutoring and educational practice. The theoretical education during the period of study at the university improves understanding of the basic ideas and concepts of tutoring. The practice-oriented approach makes it possible to simulate the process of tutor support during the distributed practice, bearing in mind the organizational and pedagogical conditions of the place for the practice.

The compilation of the program factored in the demands of the regional and Russian labour market for qualified specialists who will be ready to accompany students with various needs professionally. In the course of the analysis of the provisions of the Professional Tutor Standard, Federal State Educational Standards of Higher and General Education the researchers made up a list of necessary competencies.

All educational results of the graduates of the Bachelor's program (integrating the requirements for a tutor as a specialist) have been divided into three levels: reproductive, productive and constructive.

The reproductive level means that the student understands the principle of the practiced pedagogical action from the point of view of its individual components.

In turn, the productive level demonstrates the student's understanding of the very principle of implementing pedagogical activity in practice as a whole, as well as within the system of all its interrelated components.

The constructive level characterizes the transformation by students of a wellknown for them holistic principle of turning pedagogical action into a new one (author's specifics).

During the period of study at the university the minimum level of "digestion" of the content of the disciplines and practices of the main educational program for the bachelor degree corresponds to the productive level. The multilevel structure of the programs' educational results grants each student a right to master the competencies at an individual pace, to the individual extent and with varying complexity. Accordingly, to ensure the implementation of the basic "Tutor" program there is a number of requirements that expand the content and elaborate on the material through optional classes, differentiating and elective courses, and through student participation in social, pedagogical projects and educational events held at the institute.

A new approach to training tutors at the Institute of Education, Psychology and Sociology of Siberian Federal University (SFU) is based on the modular principle of creating a program and organizing networking of educational organizations. The 
network includes tutoring centres, schools of the Krasnoyarsk Krai, Moscow Tutor Centre, Interregional Tutor Association and practicing tutors of Russia and abroad.

Networking has significant potential for teaching tutors. Due to the network interaction, pedagogical teams engaged in teaching tutors have the opportunity to present and describe their activities systematically, to act as supervisors for students. In the course of this work, some educational organizations become aware of their falling behind or they realise that they are not sufficiently prepared to build and implement partnerships.

The developed program "Tutor" defines and specifies the conceptual foundations of practice-oriented training of teachers, the conceptual model of practice-oriented training of tutors, which is based on an understanding of the need to create a single educational space uniting university and school.

Practical orientation of pedagogical education is maintained by the focus on the forming and developing competencies necessary for the realisation of purposeful activities in the managed guidance of the future tutors and the developing of students in accordance with their most pronounced advantages potentially important to society, as well as the enhancing their ability for self-development.

\section{Discussion}

The program consists of five modules: humanities and economics, natural science, information, communication, technology. The systematic mastering of the content of the modules of the basic educational program contributes to the emergence of students' theoretical knowledge and professional competencies for outlining a professional path for the tutor's development.

The modular principle of building the program allows students to get an understanding of how the educational results obtained at the university are applicable in professional activities (Korshunova, Smolianinova, Iudina, 2014). The overall workload of the program is 240 hours, including 40 hours devoted to independent work, oriented to the creation of students' own internal motivation for learning, thinking, imagination, creative abilities, sustainable cognitive interest. In order to conduct classes, it is crucial to take into account the mechanisms of variability of studies, which make it possible to make an individual curriculum adequate to the requirement for professional development (Aleksandrova, Andreeva, 2013).

One of these forms is interdisciplinary workshops, which provide a gradual quasiimmersion in the professional environment, which stimulate the formation of the future specialist's readiness to demonstrate tutor support. 
The introduction of workshops and interactive lectures in the educational process can substantially improve the effectiveness of training. The selection of the content of the educational material and its presentation, also for the distance education environment (Kovaleva, Zhilina, 2010), is important. The content in the practice-oriented approach presupposes a focus on the practical significance of the acquired knowledge and the application of the students' experience backed up by the competencies obtained. The practice of professional tests in the period of university study becomes the basis for the development of professionalism.

The process of training tutors is inseparable from practice, which aims to endow students with practical experience in the form of professional activity. The share of the practice and workshops is $1 / 3$ of the total amount of workload. Practical lessons are given in the form of trainings, business games, master classes. The practice is an axis of the whole course running from the $1^{\text {st }}$ to the $8^{\text {th }}$ term.

The purpose of the practice is to organize the conditions for the student to move smoothly from the setting of learning tasks based on the material of different disciplines to the applied professional tasks based on the practice.

The program "Tutor" provides for the practice of various types: the practice of obtaining primary professional skills and abilities, the practice of obtaining professional skills and experience, the pre-diploma practice.

In the early stages of the practice, students thoroughly observe the realisation of tutor assistance at various levels of education. A meaningful result of this type of practice is the students' understanding of the logic of organizing a tutelage, taking into account age characteristics and individual needs of a student.

The subsequent stages of the practice involve the professional apprenticeship, reflection and rethinking during the supervision.

Supervision of a student during apprenticeship allows educators to identify professional deficiencies during the period of university study and to create motivation for further studying at the program.

During the practice of obtaining professional skills and professional experience at the second course, students have performed the first practical, though tentative activities using the relevant material in the new educational conditions.

This gave students the chance to begin mastering modern pedagogical tools and technologies, to act wisely when performing the proposed practice task, to conjure up their own ideas and realise them.

During the third and fourth courses of the university study program, it is planned to organise a practice of obtaining professional skills and professional experience. 
This type of practice is targeted at the inclusion of the student in the independent professional activity, at choosing the direction of tutor support and the level of education for tutelage.

The systematic involvement of the trainees-tutors in the educational process facilitates their interaction with the students, interaction with narrow specialists, making the communication productive, and, as a result, the development and maintenance of the individual educational program for each student. This experience of professional activity is got in a specific educational institution under supervision by a working specialist - certified tutor.

This type of practice presupposes the conscious professional action of the student and the reflection expressed by the supervisor. This practice forms the professional competencies of the future tutor, as a rule, at the reproductive and productive levels.

During the final $8^{\text {th }}$ term, the implementation of the program involves the prediploma practice. It is based on empirical research and entails writing the final qualification paper.

Thus, the logic of mastering practices and disciplines allows the student to make the first professional steps, to find if there is a lack of their own psychological and pedagogical knowledge and more thoughtfully approach the organization of their own educational path during the university study period.

An essential part of creating the individual educational route during the implementation of a practice-oriented program is an educational event. The educational event means a special form of organization of joint educational activities of studentstutors, university professors and network partners, which is aimed at meeting the need for raising the level of qualification.

Eventuality during the tutor's education contributes to the development of students' motivation and their participation in various types of professional activity, partaking in social and pedagogical projects. The involvement of students in educational events is a certain transition between theory and practice to real professional independent activity.

Practice-oriented training infers the participation of students (future tutors) in the design of educational events and their running.

Thus, the educational event is a part of the educational modules and the entire educational process. The task of preparing a tutor who will be qualified enough to develop student's ability to learn independently is solved by creating an open educational space that motivates independent professional pedagogical actions and develop ability to reflect on these actions. 


\section{Methods and methodology}

The training of tutors in a practice-oriented model at the bachelor level was not chosen randomly as a topic for research, since education is one of the social agents which promote standards. Among the leading principles of practiceoriented learning are the following: flexibility and dynamism of updating educational and professional programs; realisation of academic mobility in higher education; modularity of programs and academic disciplines; variety of forms for classroom work. The practice-oriented model of training means that students acquire an educational program in an innovative format through first professional steps. Formation of students' professional competencies is achieved via solving real practical tasks in the process of their supervising by senior teachers. In practice-oriented approach, it is imperative to evaluate the results of activity, organized reflection and self-reflection on the event (Memorandum nepreryvnogo..., 2006).

\section{Conclusion/Results}

In the SFU model, practice-oriented training of tutors is organized on the basis of network interaction of educational organizations realising higher education programs and institutions organising student practice. In 2019, the first generation of bachelorstutors will graduate from SibFU.

It is worth noting that of the 39 graduates of the program at the moment a third of the students have been invited to work as tutors. About 15 students regularly carry out professional volunteer activities at the institutions where their apprenticeship took place.

\section{References}

Aleksandrova, E.A., Andreeva, E.A. (2013). Teoriia i praktika tiutorskoi deiatel'nosti v Rossii [Theory and practice of tutor activity in Russia]. In Izv. Sarat. un-ta Nov. ser. Ser. Akmeologiya obrazovaniya. Psihologiya razvitiya [Izv. Saratov Univ. (N. S.). Ser. Educational Acmeology. Developmental Psychology], 2, 2, 222-232.

Bespalova, G.M. (2007). Tutor support: organizational forms and educational effects. In School Director, 7, 51-58.

Kasprzhak, A.G., Kalashnikov, S.P. (2014). Priority of educational results as a tool for the modernization of teacher training programs. In Psychological Science and Education, 3, 87-104. 
Korshunova, V.V., Smolianinova, O.G., Iudina, Iu.G. (2014). New model of training primary school teachers: Approbation stage - Siberian version. In Science and School, 6, 34-48, available at: http://elibrary.ru/item.asp?id=22703542

Kovaleva, T.M., Zhilina, M.Iu. (2010). Environment and event: on the didactic of tutor support. In Krylova, N.B., Zhilina M.Iu. Events in educational and pedagogical activity. New values of formations, 1 (43), 94-101.

Kovaleva, T.M. (2013). Universal methods are impossible (families with whom tutor's work is too different). In School Management, 3, 11-14.

Margolis, A.A. (2014). Requirements for the modernization of basic vocational educational programs (VEP) for the training of pedagogical personnel in accordance with the teacher's professional standard: proposals for implementing an activity approach in training pedagogical personnel. In Psychological Science and Education, $19,3,105-126$.

Memorandum nepreryvnogo obrazovaniya Evropejskogo Soyuza [A Memorandum on Lifelong Learning of the European Union] (2006). In Adukatar, 2 (8), 24-27.

Smolianinova, O., Bekuzarova, N., Ermolovich, E., Sedykh, T. (2015). The Program of Training of Tutors at the Siberian Federal University. In Professional Education in Russia and Abroad, 4 (20), 99-105.

\title{
Практико-ориентированный подход к обучению тьюторов в Сибирском федеральном университете
}

\author{
В.В. Коршунова \\ Сибирский федеральный университет \\ Россия, 660041, Красноярск, пр. Свободный, 79
}

В статье продемонстрировань возможности практико-ориентированного подхода в региональной системе образования тьюторов, востребованных в новых социальных условиях Сибири.

Эмпирической базой исследования служит анализ рынка образовательных услуг по подготовке тьюторов в России и запросы, предъявленные региональными заказчиками к специалисту-тьютору.

В качестве показателей подготовки тьюторов выделены уровни образовательных результатов в соответствии с требованиями ФГОС ВО и профессионального стандарта тьютора.

Практико-ориентированная подготовка бакалавров, основанная на изменении содержания обучения, увеличении доли практики и практических занятий, способствует 
выстраиванию стратегий профессионального роста будущих тьюторов, укреплению адекватной профессиональной самооценки и развитию личности специалиста.

Авторы предлагают новую модель практико-ориентированной подготовки тьюторов, предполагающую участие в образовательных событиях и профессиональные пробы в период обучения в университете.

В статье описан опьт ИППС Сибирского федерального университета по усилению практической составляющей профессиональной подготовки, выбора вариантов проведения занятий, их методического обеспечения с учетом инновачионного выстраивания практик студентов направления подготовки «Педагогическое образование (профиль «Тьютор»)».

Ключевые слова: практико-ориентированная подготовка, тьюторы, тьюторское сопровождение, профессиональные компетенции.

Научная специиальность: 13.00.00 - педагогические науки. 